\title{
Intestinal Morphology, Energy Availability, and Growth Performance of Broilers Treated with the Combination of Probiotic and Inulin
}

\author{
H. Julendra ${ }^{\mathrm{a}, \mathrm{b},},{ }^{,}$, A. Sofyan ${ }^{\mathrm{b}}$, L. Istiqomah ${ }^{\mathrm{b}}$, M. F. Karimy ${ }^{\mathrm{b}}$, Abinawanto ${ }^{\mathrm{a}}$, \& Yasman $^{\mathrm{a}}$ \\ ${ }^{a}$ Department of Biology, Faculty of Mathematics and Natural Sciences, Universitas Indonesia, \\ Jalan Lingkar Kampus Raya, Depok, Jawa Barat 16424, Indonesia \\ bResearch Group of Bio-Feed Additive Technology, Research Division for Natural Product Technology- Indonesian \\ Institute of Sciences (BPTBA-LIPI), \\ Jalan Jogja-Wonosari Km. 31.5 Gading, Playen, Gunungkidul, D.I. Yogyakarta 55861, Indonesia \\ ${ }^{*}$ Corresponding author: julendra1969@gmail.com \\ (Received 27-04-2020; Revised 09-07-2020; Accepted 15-07-2020)
}

\begin{abstract}
Probiotic and prebiotic or their combinations can potentially function as an alternative to antibiotics growth promoters (AGPs) for broiler. This study was designed to investigate the growth performance, intestinal microstructure, and nutrients digestibility of broilers administered with probiotics of Lactobacillus plantarum AKK30 and Saccharomyces cerevisiae B18 in combination with inulin. A total of 275 male chickens (initial bodyweight of $47 \pm 0.05 \mathrm{~g}$ ) were reared for growth performance evaluation. At the 32-d-old, 25 male chickens were necropsied for intestinal microstructural analysis, while the other 25 male chickens were selected for evaluation of digestibility (body weight= $1525 \pm 0.08 \mathrm{~g}$ ). Treatments of probiotics in combination with different levels of inulin consisted of control with probiotics without inulin (S0), probiotics with $0.5 \%$ of inulin (S1), probiotics with $1.0 \%$ of inulin (S2), probiotics with $1.5 \%$ of inulin (S3), and commercial probiotics without inulin (Sc), which were arranged in a completely randomized design with five replications. Results showed that body weight gain and performance index in broilers treated prebiotics in combination with $0.5 \%$ inulin (S1), $1 \%$ inulin (S2), and commercial probiotic without inulin (Sc) were significantly higher $(p<0.05)$ than those in control broiler chickens that were treated with probiotics without inulin. Feed intake showed no differences among treatments, whereas feed conversion ratios in broiler chickens treated with the commercial probiotics (Sc) or probiotics in combination with inulin at $0.5 \%$ (S1) and $1.0 \%$ (S2) were lower than control chickens. Metabolizable energy, nitrogen retention, and villi height in chickens treated with probiotics in combination with $0.5 \%$ inulin (S1) and $1.0 \%$ inulin (S2) were higher than those in the control group. In conclusion, the administration of probiotic combined with inulin at the level of either 0.5 or $1.0 \%$ improves broiler performance, intestinal microstructure, and nutrients digestibility.
\end{abstract}

Keywords: probiotic; inulin; growth performance; intestinal microstructure; metabolizable energy

\section{INTRODUCTION}

Antibiotics growth promoters (AGPs) have played an important role in improvement of feed efficiency and poultry productivity. However, long-term use of AGPs has led to pathogenic bacteria resistances in poultry, which affect the potential risk to human health (Ricke et al., 2020). Therefore, the exploration of alternative substances for replacing AGPs has been extensively elucidated. Previous studies indicated that organic acids (Salah et al., 2019), phytobiotics (Ripon et al., 2019), prebiotics (Iriyanti et al., 2018), and probiotics (Sofyan et al., 2019) have potencies for replacing AGPs.

Probiotics administration gives some benefits to the enhancement of poultry performance. Probiotics produce antimicrobial substances for inhibiting the pathogenic bacteria (Mehdi et al., 2018) and increasing feed digestion in the digestive tract (Sofyan et al., 2019). Prebiotic is known as non-digestible carbohydrates that selectively stimulate the growth of beneficial bacteria in the small intestine and caecum (Iriyanti et al., 2018). Beneficiary effects of probiotics and prebiotics have potentially improved animal health (Mohammed et al., 2019). Varies factors possibly affect the role of prebiotics in modulating the role of probiotics in improving broiler performance, which were depending on the types and level of oligosaccharides administration (KowalczukVasilev et al., 2017).

Several studies reported that probiotics and prebiotics improved health status and performances of chickens. Jiang et al. (2020) revealed that the addition of probiotics in combination with fructo-oligosaccharides improved the health status of chicken without increasing feed efficiency. Villagrán-de la Mora et al. (2019) 
reported that the addition of probiotic and prebiotic in chicken could inhibit pathogenic bacteria and improve mucosal immunity. A study reported by Sarangi et al. (2016) stated that dietary inclusion of probiotic and prebiotic did not show an increase in growth performances and meat qualities of broiler chickens. However, probiotics used in those studies consisted of bacterial strain only. In a previous study, the use of a combination of bacteria and yeast improved antibacterial activity (Sofyan et al., 2019). The study of probiotics consortia between bacteria and yeast on growth performance, immune system, and intestinal microbiota of chickens is still limited.

The present study was conducted to investigate the effects of dietary supplementation of probiotics consisting of Lactobacillus plantarum AKK30 and S. cerevisiae B18 in combination with inulin prebiotic on metabolizable energy, intestinal profile, as well as the growth performance of broiler chickens.

\section{MATERIALS AND METHODS}

The Bio-ethics Committee of the Universitas Gadjah Mada (UGM) approved this research protocol with the recommendation letter number 00051/04/LPPT/X/2019. Broiler chickens were reared in poultry experimentally closed house belongs to the Research Division for Natural Product Technology (BPTBA), Indonesian Institute of Sciences (LIPI), Gunungkidul, Yogyakarta, Indonesia

\section{Experimental Chickens Management and Feeding}

Two hundred and seventy-five of one-day-old (DOC) male broilers of Lohmann MB 202 strain were obtained from the closest commercial hatchery (PT Japfa Comfeed, Indonesia). DOCs were vaccinated directly in the hatchery facility with ND, IB, and IBD vaccines. The experimental broilers were reared for 32 days and supplied diet and drinking water ad libitum.

The poultry closed house $(8 \times 10 \mathrm{~m})$ was equipped with two blowers, temptron 304, cooling-pad, and brooder. The experimental broilers were supported in continuous light conditions during the first two weeks, and $18 \mathrm{~h}$ light $/ 6 \mathrm{~h}$ dark cycles for the rest of the experiment. Room temperature was set at $33 \pm 1^{\circ} \mathrm{C}$ for five days and gradually reduced by $1^{\circ} \mathrm{C}$ per day until it reached $24 \pm 1^{\circ} \mathrm{C}$, and this temperature was kept for the rest of the experiment. Poultry closed house was disinfected with 200 ppm chlorine solution before the broilers arrived. The experimental broilers were reared in pens ( 25 pens) to prevent contact between group treatments with the maximum stocking density of 10 chickens $\mathrm{m}^{-2}$.

The experimental broilers were reared and treated according to the guide for the care and use of agricultural animals in research and teaching (McGlone, 2010) as well as Lohmann MB 202 management guided (JCI, 2020). The broilers diet was formulated according to the recommendations of nutrient requirement for broiler chicken (NRC, 1994). The composition and nutrient content of the diet were shown in Table 1. The experimental broiler chickens were fed the crumble diets during the experiment. Growth performance parameters measured consisted of feed intake (FI), body weight gain (BWG), and feed conversion ratio (FCR), as well as the performance index (PI) of broilers were evaluated at the age of 32 days. The performance index was calculated refers to Sofyan et al. (2012) using the following equation.

$\mathrm{PI}=[\mathrm{BWG} \times(100-\%$ mortality $)] /[\mathrm{FCR} \times 100 \times$ period $]$

FI was recorded by cumulative collections during the starter period ( 1 to $15-\mathrm{d}-\mathrm{old}$ ) and finisher period (16 to 32-d-old). At the end of the experimental period (32-d-old), one broiler chicken per replicate (a total of 25 broiler chickens) was randomly sampled, weighed, and necropsied for intestinal microstructural observations. Then 30 male broiler chickens were selected for metabolic energy assays with the average body weight of $1525 \pm 0.08 \mathrm{~g}$.

\section{Probiotics Preparation and Experimental Design}

Probiotics in this experiment consisted of $L$. plantarum and S. cerevisiae B18 (The collected isolates

Table 1. Composition (\%) and nutritional content of basal diet

\begin{tabular}{lcc}
\hline \multirow{2}{*}{ Ingredients } & \multicolumn{2}{c}{ Composition $(\%)$} \\
\cline { 2 - 3 } & Starter & Finisher \\
\hline Corn & 60.50 & 62.30 \\
Rice bran & 0.00 & 2.30 \\
SBM (Soy Bean Meal) & 30.00 & 26.00 \\
MBM (Meat and Bone Meal) & 1.70 & 2.20 \\
CPO (Crude Palm Oil) & 2.30 & 2.90 \\
Premix & 0.50 & 0.50 \\
DCP (Dicalcium Phosphate) & 0.50 & 0.50 \\
Salt & 0.10 & 0.10 \\
Limestone & 1.3 & 1.40 \\
L-Lysine & 1.7 & 1.20 \\
DL-Methionine & 1.0 & 0.60 \\
Total (\%) & 100 & 100 \\
Nutrients content ${ }^{* *}$ & & \\
Dry matter (\%) & 91.17 & 91.02 \\
Ash (\%) & 4.92 & 5.21 \\
Crude protein (\%) & 22.95 & 21.89 \\
Crude fiber (\%) & 2.75 & 5.98 \\
Ether extract (\%) & 4.23 & 3.75 \\
Calcium (\%) & 2.24 & 2.63 \\
Total phosphorus (\%) & 0.74 & 0.80 \\
Amino acids*** (\%) & - & - \\
$\quad$ Lysine & 0.98 & 0.92 \\
$\quad$ Methionine & 0.22 & 0.26 \\
Metabolizable energy & 3050.87 & 3100.75 \\
\hline
\end{tabular}

Note: ${ }^{*}=$ Premix $/ \mathrm{kg}$ containing vitamins A: $12,500,000$ IU, D3: 2,500,000 IU, E: 10,000 mg, K3: 2,000 mg, B2: 4,000 mg, B6: 1,000 mg, Niacin: $40,000 \mathrm{mg}$, Ca-d-Panthotenate: 4,000 mg, Choline: $20,000 \mathrm{mg}$, Fe: $30,000 \mathrm{mg}, \mathrm{Cu}: 5,000 \mathrm{mg}, \mathrm{Mn}: 80,000 \mathrm{mg}$, Co: $2,000 \mathrm{mg}$, I $200 \mathrm{mg}$, and $\mathrm{Zn}: 70,000 \mathrm{mg}$; ${ }^{* *}=$ Results of proximate analysis at the Laboratory of Feed Science and Technology, Department of Nutrition and Feed Technology, IPB University. ${ }^{* * *}=$ Based on the Table of National Research Council (1994), ${ }^{* * * *}=$ Value was calculated based on the formula of National Research Council (1994) as follow: $\mathrm{ME}=0.725 \times \mathrm{GE}$. 
of BPTBA-LIPI), and inulin (Orafti, Beneo-USA). The probiotics were made from a suspension of $50 \%\left(\mathrm{w} \mathrm{v}^{-1}\right)$ L. plantarum AKK30 $\left(10^{8} \mathrm{cfu} \mathrm{g}^{-1}\right), 50 \%\left(\mathrm{w} \mathrm{v}^{-1}\right)$ S. cerevisiae B18 $\left(10^{7} \mathrm{cfu} \mathrm{g}^{-1}\right)$ mixed with $0,5 \%, 1,0 \%, 1,5 \%$, and $2,0 \%$ $\left(\mathrm{w} \mathrm{V}^{-1}\right)$ liquid inulin, and dried using a spray dryer. The probiotics were dissolved in water-soluble powder preparations and administered in drinking water of broiler at 1-day-old to 32-d-old. The experimental broiler chickens in all treatments were not provided drinking water from 07:15 every morning, and simultaneously started at 7:30 am. The experimental broilers chickens consumed probiotics as much as $0.3 \%$ of feed requirements (Leeson \& Summers, 2005). After finishing probiotics consumption, the experimental broiler chickens offered drinking water ad libitum starting at $9.00 \mathrm{am}$.

All experimental broiler chickens were arranged in a completely randomized design with five treatments of the combination of probiotics and inulin, each treatment with five equal replicates. The treatments consisting of probiotics with different concentrations of inulin were as follows: $50 \%$ L. plantarum AKK30 $10^{8} \mathrm{cfu} \mathrm{g}^{-1}+50 \% \mathrm{~S}$. cerevisiae B18 $10^{7} \mathrm{cfu} \mathrm{g}^{-1}$ without inulin (S0), 50\% L. plantarum AKK30 $10^{8} \mathrm{cfu} \mathrm{g}^{-1}+50 \%$ S. cerevisiae B18 $10^{7} \mathrm{cfu} \mathrm{g}^{-1}$ with inulin $0.5 \% \mathrm{w} \mathrm{v}^{-1}$ (S1), 50\% L. plantarum AKK30 $10^{8}$ $\mathrm{cfu} \mathrm{g}^{-1}+50 \%$ S. cerevisiae B18 $10^{7} \mathrm{cfu} \mathrm{g}^{-1}$ with inulin $1.0 \%$ $\mathrm{W} \mathrm{v}^{-1}$ (S2), $50 \%$ L. plantarum AKK30 $10^{8} \mathrm{cfu} \mathrm{g}^{-1}+50 \% \mathrm{~S}$. cerevisiae B18 $10^{7} \mathrm{cfu} \mathrm{g}^{-1}$ with inulin $1.5 \% \mathrm{w} \mathrm{v}^{-1}$ (S3), and the commercial probiotic (Green Culture ZS, Han Poong Co. Ltd., Korea) (Sc). Parameters observed were performance, intestinal profile, metabolizable energy (ME), and nitrogen retention (NR).

\section{Small-Intestine Microstructure}

The analysis of intestinal microstructure was performed to measure the height of villi using Scanning Electron Microscope/SEM (Hitachi-SU3500). Twenty-five experimental broiler chickens 32-d of age, one chicken from each pen were taken randomly and necropsied. A sample of the small intestine was collected from jejunum intestine $(10 \mathrm{~cm})$ which was taken from the proximal of Meckel's diverticulum. The sample was washed by a phosphate buffer solution then the sample was placed into a $10 \%$ formalin solution. Villus height (VH) of intestinal sample was determined by scanning electron microscopy (Titze \& Christel, 2016).

\section{Sample Collection and Chemical Analysis}

Determination of metabolizable energy (ME) and nitrogen retention (NR) were conducted according to Sibbald \& Wolynetz (1985), as previously described by Sofyan et al. (2019). Briefly, a total of 25 male experimental broiler chickens at 32-d-old (body weight $=1525 \pm 0.08$ g) were reared and randomly distributed in the individual pen (width $30 \mathrm{~cm} \times$ length $40 \mathrm{~cm} \times$ height $40 \mathrm{~cm}$ ). The amount of five male birds were also reared in the individual pen as indigenous groups. After fasting for 24 hours, the experimental broiler chickens were given diet (137 g/bird) except indigenous group. Broiler chickens at treated groups were orally offered the diluted probiotic, prebiotic, and its combination $(0.3 \% \times \mathrm{FI}$ (g/bird).
All excreta from treatment and indigenous birds were collected continuously for $24 \mathrm{~h}$ and immediately dried by oven at $60^{\circ} \mathrm{C}$.

The feed samples were analyzed for dry matter (AOAC, 2005), nitrogen (AOAC, 2005), and gross energy determined in bomb calorimeter Parr®6200 Oxygen (Parr Instrument Company, USA).

The excreta samples were dried in forced-air oven at $50-60^{\circ} \mathrm{C}$ for 72 hours and ground in disk mill with 80 mesh sieves. Furthermore, dry matter and nitrogen of samples were analyzed according to AOAC (2005) and gross energy determined in bomb calorimeter Parr®6200 Oxygen (Parr Instrument Company, USA).

Determination of metabolizable energy (ME) and nitrogen retention (NR) were estimated according to Sibbald \& Wolynetz (1985) as previously reported by Sofyan et al. (2019) by following the formula:

AME $\left(\mathrm{kcal} \mathrm{kg}^{-1}\right)=\{($ E-ingested - E-excreted $) /$ Feedintake $\} \times 1000$

AMEn $\left(\mathrm{kcal} \mathrm{kg}^{-1}\right)=\{($ E-ingested $-[$ E-excreted $+(8.22 \times$ NR)] $) /$ Feed intake $\times 1000$

$\mathrm{TME}\left(\mathrm{kcal} \mathrm{kg}^{-1}\right)=\{[$ E-ingested $-($ E-excreted + E-endogenous $)] /$ Feed intake $\} \times 1000$

TMEn $\left(\mathrm{kcal} \mathrm{kg}^{-1}\right)=\{($ E-ingested $-[$ E-excreted + E-endogenous $+(8.22 \times \mathrm{NR})]) /$ Feed intake $\mathrm{x} \times 1000$

$\mathrm{NR}(\%)=\{[\mathrm{N}$-ingested $-(\mathrm{N}$-excreta $-\mathrm{N}$-endogenous $)] /$ $\mathrm{N}$ intake $\mathrm{x} \times 100 \%$

where AME is apparent ME $\left(\mathrm{kcal} \mathrm{kg}^{-1}\right)$, AMEn is apparent ME with nitrogen correction $\left(\mathrm{kcal} \mathrm{kg}^{-1}\right)$, TME was true ME ( $\left.\mathrm{kcal} \mathrm{kg}^{-1}\right)$, TMEn is true ME with nitrogen correction $\left(\mathrm{kcal} \mathrm{kg}^{-1}\right), \mathrm{E}$ is energy, $\mathrm{N}$ is nitrogen, and 8.22 is coefficient of energy value from uric acid ( $\left.\mathrm{kcal} \mathrm{g}^{-1} \mathrm{RN}\right)$.

\section{Statistical Analysis}

The collected data consisted of broiler performance, intestinal profile, metabolizable energy (ME), and nitrogen retention (NR) were analyzed by ANOVA. The Duncan post hoc test was run by CoSTAT statistical software (Cohort, 2008) for distinguishing different effects among treatments. Interrelationship patterns between parameters were analyzed by multivariate cluster analysis (Sofyan et al., 2019) which was visualized by dendroheatmap in R-statistical software (Warnes et al., 2019).

\section{RESULTS}

\section{Growth and Performance Index of Chicken}

Growth performance consisted of feed intake, body weight gain (BWG), feed conversion ratio (FCR), and performance index (PI) of experimental broiler chickens during the starter period (1 to 15-d-old) and finisher period (15 to 32-d-old) were summarized in Table 2. During the experiment, feed intake among treatments both during starter and finisher periods. However, BWG of control broiler chickens treated with probiotic without inulin (S0) was lower compared to the other groups of experimental broiler chickens treated with probiotics in combination with inulin (S1, S2, and S3) and broiler 
chickens treated with a commercial probiotic without inulin $(\mathrm{Sc})(\mathrm{p}<0.05)$ during the starter period. However, during the finisher period, the BWGs of broiler chickens treated with probiotic in combination with $0.5 \%$ inulin (S1) and $1.0 \%$ inulin (S2) were higher $(\mathrm{p}<0.05)$ than broiler chickens treated with probiotic in combination with $1.5 \%$ inulin (S3), broiler chickens treated with commercial probiotic without inulin (Sc) and control broiler chicken treated with probiotics without inulin (S0). Moreover, during the whole period of the experiment from starter to finisher periods, BWGs of broiler chickens treated with probiotics in combination with inulin at concentrations of $0.5 \%$ (S1), $1.0 \%$ (S2), and broiler chickens treated with commercial probiotic without inulin (Sc) were higher than those of broiler chickens treated with probiotics in combination with $1.5 \%$ inulin (S3) and control broiler chickens treated with probiotics without inulin (SO).
During the starter period, the FCR in all groups of experimental broiler chickens were not significantly different. However, during the finisher period, the FCRs of broiler chickens treated with probiotics in combination with $0.5 \%$ inulin (S1) and $1.0 \%$ inulin (S2) were lower than that of control broiler chickens treated with probiotic without inulin (S0) $(\mathrm{p}<0.05)$. Performance index (PI) data showed that the administration of probiotics in combination with inulin at the levels of $0.5 \%$ (S1) and $1.0 \%$ (S2), and commercial probiotic without inulin (Sc) increased the PI $(\mathrm{p}<0.05)$ compared to control broiler chickens treated with probiotics without inulin (S0).

\section{Small-Intestine Profile}

The microstructure of villus heights $(\mathrm{VH})$ was presented in Table 3 and Figure 1. VH of the control broiler chicken treated with probiotics without combination

Table 2. Growth performance of broilers fed combination of probiotic and inulin

\begin{tabular}{|c|c|c|c|c|c|}
\hline \multirow{2}{*}{ Variables } & \multicolumn{5}{|c|}{ Treatments } \\
\hline & S0 & S1 & S2 & S3 & Sc \\
\hline \multicolumn{6}{|l|}{ Starter period, d 1-15 } \\
\hline Feed intake $\left(\mathrm{g} \mathrm{bird}^{-1}\right)$ & $455.9 \pm 1.8$ & $452 \pm 10.2$ & $454 \pm 2.8$ & $452.6 \pm 1.3$ & $453.8 \pm 14.2$ \\
\hline BWG (g bird $\left.{ }^{-1}\right)$ & $440.5 \pm 10^{a}$ & $452.7 \pm 12^{\mathrm{b}}$ & $450.2 \pm 27^{b}$ & $450.6 \pm 9^{b}$ & $453.0 \pm 21^{\mathrm{b}}$ \\
\hline FCR & $1.01 \pm 0.01$ & $1.04 \pm 0.04$ & $1.02 \pm 0.02$ & $1.01 \pm 0.03$ & $1.02 \pm 0.02$ \\
\hline \multicolumn{6}{|l|}{ Finisher period, d 16-32 } \\
\hline Feed intake $\left(\mathrm{g} \mathrm{bird}^{-1}\right)$ & $1,943 \pm 35$ & $1,946 \pm 18$ & $1,946 \pm 18$ & $1,948 \pm 42$ & $1,945 \pm 21$ \\
\hline BWG $\left(\mathrm{g} \mathrm{bird}^{-1}\right)$ & $9,68.7 \pm 45^{\mathrm{a}}$ & $1,110 \pm 22^{c}$ & $1,099 \pm 52^{c}$ & $1,006.5 \pm 21^{\mathrm{b}}$ & $1,065.5 \pm 25^{\mathrm{bc}}$ \\
\hline FCR & $2.01 \pm 0.03^{b}$ & $1.75 \pm 0.02^{\mathrm{a}}$ & $1.77 \pm 0.01^{\mathrm{a}}$ & $1.94 \pm 0.02^{\mathrm{b}}$ & $1.82 \pm 0.03^{\mathrm{ab}}$ \\
\hline \multicolumn{6}{|l|}{ Overall, d 1- 32} \\
\hline Feed intake $\left(\mathrm{g} \mathrm{bird}^{-1}\right)$ & $2,399 \pm 72$ & $2,398 \pm 68$ & $2,399.6 \pm 82$ & $2,400 \pm 43$ & $2,398 \pm 28$ \\
\hline BWG $\left(\right.$ g bird $\left.^{-1}\right)$ & $1,409.2 \pm 35^{a}$ & $1,562.7 \pm 21^{b}$ & $1,549.2 \pm 32^{b}$ & $1,457 \pm 21^{\mathrm{a}}$ & $1,518.5 \pm 15^{b}$ \\
\hline FCR & $1.70 \pm 0.07^{b}$ & $1.53 \pm 0.04^{\mathrm{a}}$ & $1.55 \pm 0.05^{\mathrm{a}}$ & $1.65 \pm 0.02^{\mathrm{b}}$ & $1.58 \pm 0.03^{\mathrm{a}}$ \\
\hline PI & $264 \pm 24$ & $314.4 \pm 10$ & $312.9 \pm 21$ & $253.8 \pm 12$ & $300.3 \pm 10$ \\
\hline Mortality (\%) & $5.46^{\mathrm{a}}$ & $0^{\mathrm{b}}$ & $0^{\mathrm{b}}$ & $3.64^{\mathrm{a}}$ & $0^{\mathrm{b}}$ \\
\hline
\end{tabular}

Note: S0 $=50 \%$ L. plantarum AKK30 10 cfu g $^{-1}+50 \%$ S. cerevisiae B18 $10^{7} \mathrm{cfu} \mathrm{g}^{-1}$ without inulin; S1 $=50 \%$ L plantarum AKK $3010^{8} \mathrm{cfu} \mathrm{g}^{-1}+50 \%$ S. cerevisiae B18 $10^{7} \mathrm{cfu} \mathrm{g}^{-1}$ with inulin $0.5 \% \mathrm{w} \mathrm{v}^{-1} ; \mathrm{S} 2=50 \%$ L. plantarum AKK30 $10^{8} \mathrm{cfu} \mathrm{g}^{-1}+50 \%$ S. cerevisiae B18 $10^{7} \mathrm{cfu} \mathrm{g}^{-1}$ with inulin $1.0 \% \mathrm{w} \mathrm{V} \mathrm{v}^{-1} ; \mathrm{S} 3=50 \% \mathrm{~L}$. plantarum AKK30 $10^{8} \mathrm{cfu} \mathrm{g}^{-1}+50 \%$ S. cerevisiae B18 $10^{7} \mathrm{cfu} \mathrm{g}^{-1}$ with inulin $1.5 \% \mathrm{~W} \mathrm{~V}^{-1}$; Sc= commercial symbiotic; BWG= body weight gain; FCR= feed conversion ratio; PI= performance index. Means in the same row with different superscripts differ significantly $(\mathrm{p}<0.05)$.

Table 3. Villi height and energy availability of broilers fed combination of probiotic and inulin

\begin{tabular}{lccccc}
\hline \multirow{2}{*}{ Variables } & \multicolumn{5}{c}{ Treatments } \\
\cline { 2 - 6 } & S0 & S1 & S2 & S3 & Sc \\
\hline Villous height $(\mu \mathrm{m})$ & $869.2 \pm 36.5^{\mathrm{a}}$ & $1,122 \pm 40.9^{\mathrm{b}}$ & $1,205.2 \pm 408.5^{\mathrm{b}}$ & $905 \pm 135^{\mathrm{a}}$ & $919.4 \pm 228^{\mathrm{a}}$ \\
Weight of excreta $(\mathrm{g} \mathrm{DM})$ & $32.9 \pm 3.1^{\mathrm{a}}$ & $20 \pm 4.9^{\mathrm{b}}$ & $21.5 \pm 3.4^{\mathrm{b}}$ & $30.4 \pm 4.5^{\mathrm{a}}$ & $29.7 \pm 4.3^{\mathrm{a}}$ \\
N-excreta $(\mathrm{g} \mathrm{DM})$ & $1.7 \pm 0.22^{\mathrm{a}}$ & $1.1 \pm 0.29^{\mathrm{b}}$ & $1.1 \pm 0.16^{\mathrm{b}}$ & $1.4 \pm 0.39^{\mathrm{ab}}$ & $1.9 \pm 0.92^{\mathrm{a}}$ \\
GE-excreta $\left(\mathrm{kcal} \mathrm{kg}^{-1}\right)$ & $2,528.6 \pm 21.9^{\mathrm{a}}$ & $3,054.9 \pm 208^{\mathrm{c}}$ & $2,852.6 \pm 80.8^{\mathrm{b}}$ & $2,875.8 \pm 42.4^{\mathrm{b}}$ & $3,038.1 \pm 42.4^{\mathrm{c}}$ \\
AME $\left(\mathrm{kcal} \mathrm{kg}^{-1}\right)$ & $2,613.47 \pm 82.2^{\mathrm{a}}$ & $2,906.13 \pm 133.7^{\mathrm{b}}$ & $2,936.60 \pm 71.2^{\mathrm{b}}$ & $2,654.51 \pm 142.6^{\mathrm{a}}$ & $2,725.24 \pm 42.6^{\mathrm{a}}$ \\
AMEn $\left(\mathrm{kcal} \mathrm{kg}^{-1}\right)$ & $2,613.66 \pm 82.2^{\mathrm{a}}$ & $2,906.38 \pm 133.7^{\mathrm{b}}$ & $2,936.84 \pm 72^{\mathrm{b}}$ & $2,654.72 \pm 142^{\mathrm{a}}$ & $2,725.45 \pm 42.6^{\mathrm{a}}$ \\
TME $\left(\mathrm{kcal} \mathrm{kg}^{-1}\right)$ & $2,717.14 \pm 82.5^{\mathrm{a}}$ & $2,999.12 \pm 127.6^{\mathrm{b}}$ & $3,020.83 \pm 71^{\mathrm{b}}$ & $2,750.45 \pm 140.6^{\mathrm{a}}$ & $2,818.82 \pm 40^{\mathrm{a}}$ \\
TMEn $\left(\mathrm{kcal} \mathrm{kg}^{-1}\right)$ & $2,717.35 \pm 82.2^{\mathrm{a}}$ & $2,999.39 \pm 127.6^{\mathrm{b}}$ & $3,021.10 \pm 71^{\mathrm{b}}$ & $2,750.68 \pm 139.6^{\mathrm{a}}$ & $2,819.05 \pm 40^{\mathrm{a}}$ \\
NR $(\%)$ & $67.2 \pm 5.5^{\mathrm{a}}$ & $83.9 \pm 7.3^{\mathrm{b}}$ & $85.7 \pm 3.3^{\mathrm{b}}$ & $74.9 \pm 9.3^{\mathrm{a}}$ & $71.04 \pm 14.2^{\mathrm{a}}$ \\
\hline
\end{tabular}

Note: S0= control; S1= Probiotic + inulin 0.5\%; S2= Probiotic + inulin 1.0\%; S3= Probiotic + inulin $1.0 \%$; Sc= commercial probiotic. ${ }^{*}$ isolated in caecum broiler sample; $\mathrm{N}=$ nitrogen; $\mathrm{GE}=$ gross energy; $\mathrm{AME}=$ apparent metabolizable energy; $\mathrm{AMEn}=$ apparent metabolizable energy and corrected by $\mathrm{N}$-energy; TME= true metabolizable energy; TMEn= true metabolizable energy and corrected by N-energy; NR= nitrogen retention. Means in the same row with different superscripts differ significantly $(\mathrm{p}<0.05)$. 


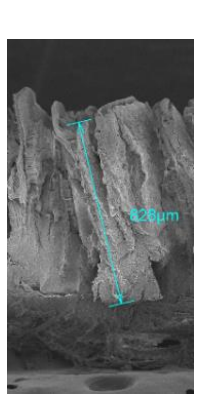

1

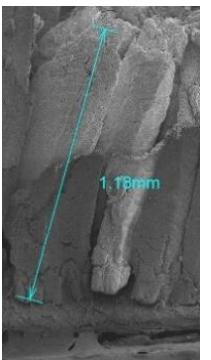

1

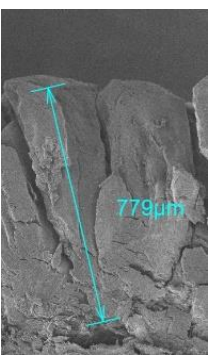

1

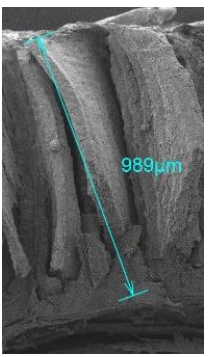

1

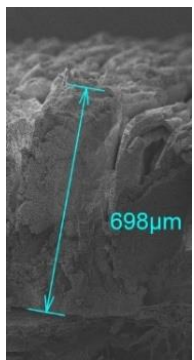

1

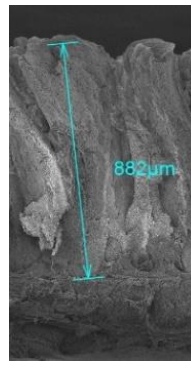

2

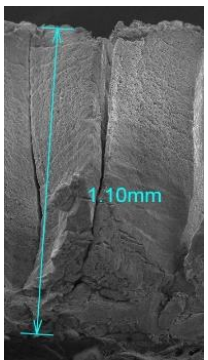

2

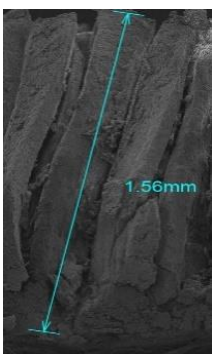

2

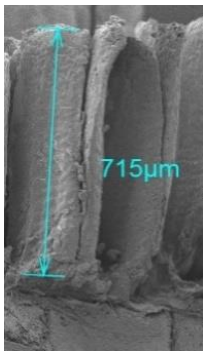

2

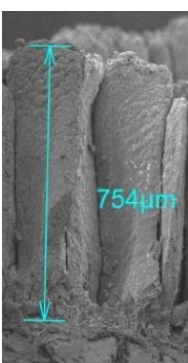

2

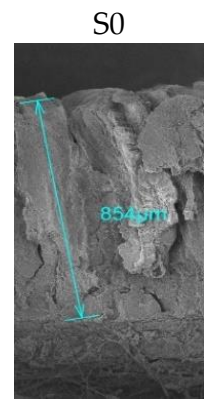

3

S1

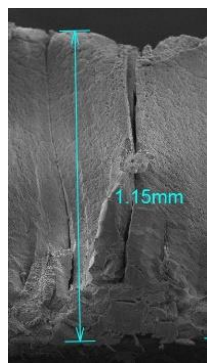

3

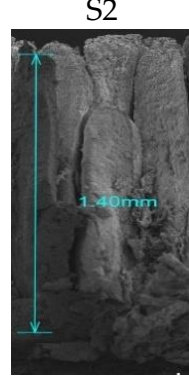

3

S3

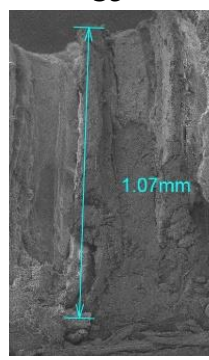

3

Sc

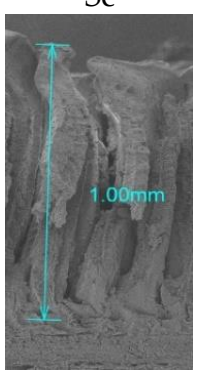

3

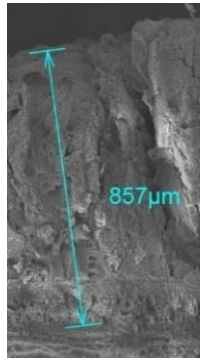

4

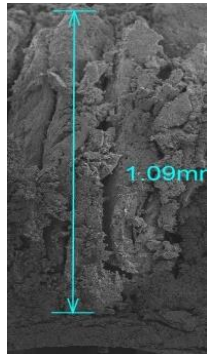

4

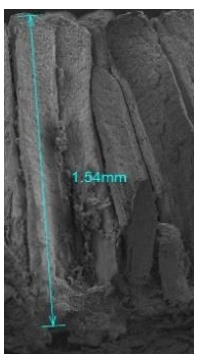

4

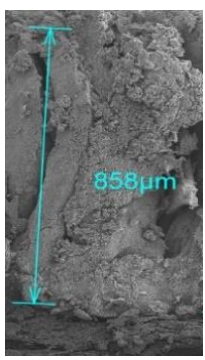

4

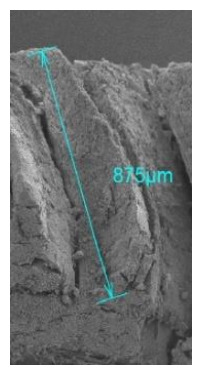

4

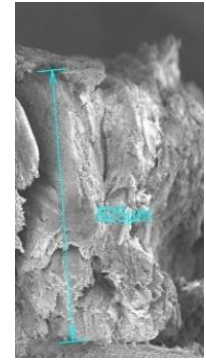

5

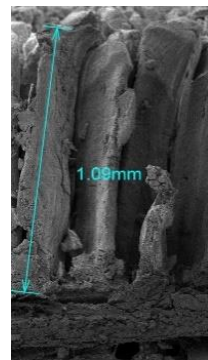

5

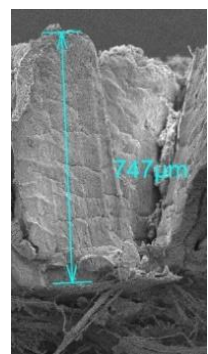

5

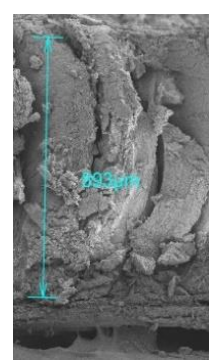

5

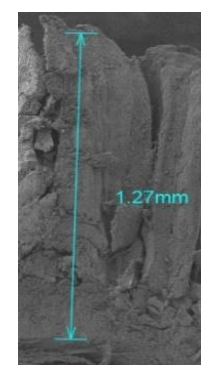

5

Figure 1. Image of jejunum villi height by using scanning electron microscope. Jejunum villi height of $\mathrm{S} 0=$ control; $\mathrm{S} 1=$ Probiotic + inulin $0.5 \%$; $\mathrm{S} 2=$ Probiotic + inulin $1.0 \%$; $\mathrm{S} 3=$ Probiotic + inulin $1.0 \%$; $\mathrm{Sc}=$ commercial probiotic. Each treatment consisted of replication 1,2 ..5. Image processing using scanning electron microscope (Hitachi SU-3500) to measure the height of jejunum villi. 
with inulin was lower than those of broiler chickens treated with probiotics in combination with $0.5 \%$ inulin (S1) and $1.0 \%$ inulin (S2) $(\mathrm{p}<0.05)$. However, VHs of broiler chickens treated with probiotics in combination with $1.5 \%$ inulin (S3) and broiler chickens treated with commercial probiotic without inulin $(\mathrm{Sc})$ were not significantly different compared to control broiler chickens treated with probiotics without inulin. $\mathrm{VH}$ in broiler chickens treated with probiotics in combination with 1\% inulin (S2) was higher than that in the other groups, but broiler chickens treated with probiotics in combination with $1.0 \%$ inulin (S2) did not significantly differ compared to broiler chickens treated with probiotics in combination with $0.5 \%$ inulin (S1). Based on SEM images (Figure 1), the VHs of all broiler chickens treated with probiotics in combination with inulin at the levels of $0.5 \%(\mathrm{~S} 1), 1.0 \%(\mathrm{~S} 2)$, and $1.5 \%$ (S3) as well as broiler chickens treated with commercial probiotics without inulin (Sc) were higher than the control broiler chickens treated with probiotics without inulin (S0). The surfaces of villi in the control broiler chickens supplemented with probiotics without inulin showed many disturbances that were characterized by the irregular surfaces of the villi.

\section{Nutrients Utilization and Interrelationship Between Parameters}

Nutrients utilization parameters consisted of metabolizable energy (ME) and nitrogen retention (NR) of the experimental broiler chickens were summarized in
Table 3. The metabolizable energy (ME) and nitrogen retention (NR) of experimental broiler chickens treated with probiotics in combination with inulin at the level of $0.5 \%$ (S1) and $1.0 \%$ (S2) were higher than the other groups $(\mathrm{p}<0.05)$. Meanwhile, nitrogen retentions (NR) in control broiler chickens treated with probiotics without inulin (S0), broiler chickens treated with probiotics in combination with inulin at the level of $1.5 \%$ (S3), and broiler chickens treated with commercial probiotics without inulin $(\mathrm{Sc})$ were significantly different from broiler chickens treated with probiotics in combination with inulin at the levels of $0.5 \%$ (S1) and 1.0\% (S2) $(\mathrm{p}<0.05)$.

Interrelationships between growth performances, villus heights, nutrients utilization were visualized in Figure 2. Broiler chickens treated with probiotics in combination with inulin at the levels of $0.5 \%$ (S1) and $1 \%$ (S2) were categorized in the same cluster having the higher growth performance, villi height, and nutrients utilization.

\section{DISCUSSION}

Dietary probiotics and prebiotics have potencies for altering the structures of intestinal mucosa of broilers (Śliżewska et al., 2020; Jiang et al., 2020). Antibacterial activity in probiotics can reduce colonization of pathogenic bacteria in the intestine resulting in the optimal growth of villous (Villagrán-de la Mora et al., 2019). Nutrient utilization and absorptions are strongly influenced by the growth of villi because the absorption cells,

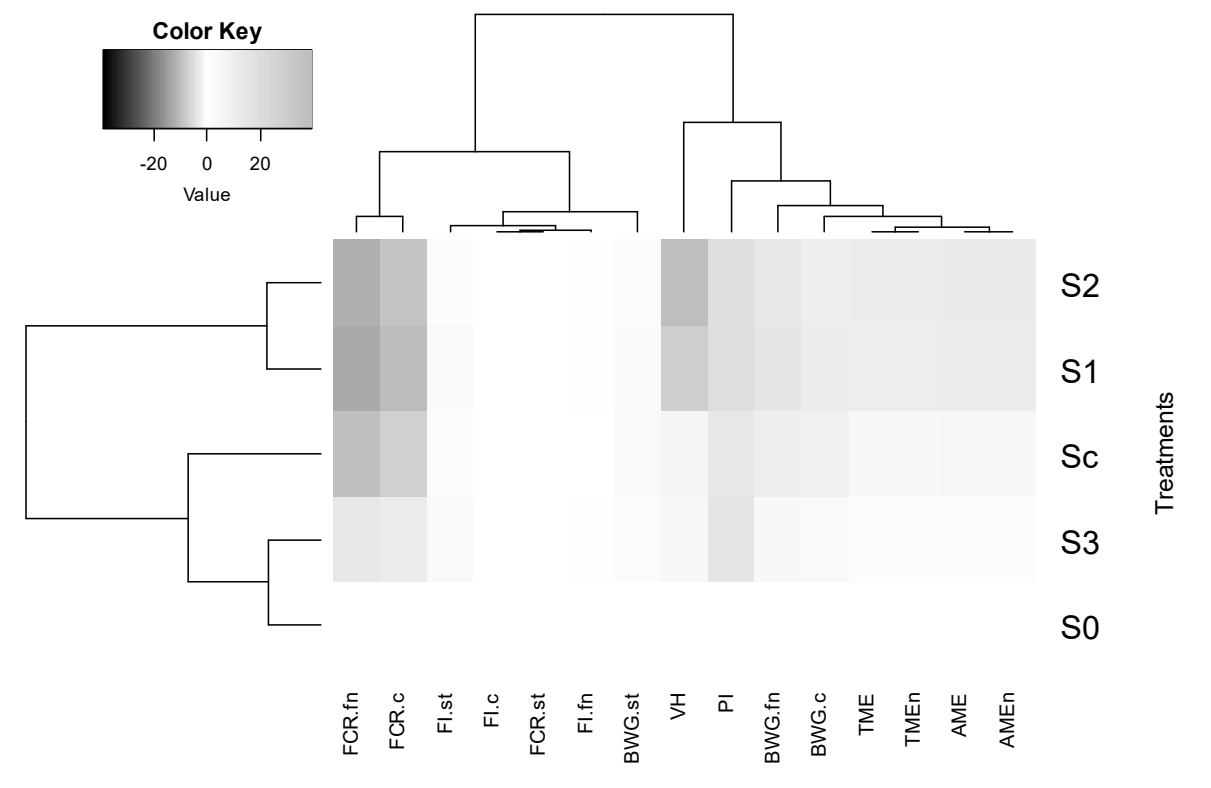

Figure 2. Interrelation between performance, villi height, and digestibility using dendroheatmap. S0 = control; S1= Probiotic + inulin $0.5 \%$; S2= Probiotic + inulin $1.0 \%$; S3= Probiotic + inulin 1.0\%; Sc= commercial probiotic; FI.st= feed intake at starter period; BWG.st= body weight gain at starter period; FCR.st= feed conversion ratio at starter period; FI.fn= feed intake at finisher period; BWG.fn= body weight gain at finisher period; FCR.fn= feed conversion ratio at finisher period; FI.c= feed intake cumulative; BWG.c $=$ body weight gain cumulative; FCR.c $=$ feed conversion ratio cumulative; $\mathrm{PI}=$ performance index; $\mathrm{VH}=$ villi height; $\mathrm{AME}=$ apparent metabolizable energy; $\mathrm{AMEn}=$ apparent metabolizable energy corrected by N-energy; TME= true metabolizable energy, TMEn= true metabolizable energy corrected by N-energy. 
trophy cells, and entero-endocrine cells from the surface of the villi serve to expand the area of absorption (Yadav \& Rajesh, 2019). The presence of pathogenic bacteria in the crypt villous area inhibits nutrient flow that eventually disturbs nutrients absorption (Gadde et al., 2017; Villagrán-de la Mora et al., 2019).

Synbiotic showed a beneficial alteration in the intestinal microbiota composition, an increase in villi height, and crypt depth of intestinal mucosa in broilers (Sohail et al., 2012). Tayeri et al. (2018) reported that feeding commercial synbiotic to broiler chickens resulted in higher villus widths in the ileum. In this study, intestinal villi of broilers chickens treated with probiotics and inulin $(0.5 \%$ and $1.0 \%)$ were higher than that of the other treatments. These results indicate that the effects of probiotics administration on gut morphology may be dependent on inulin concentration.

Probiotics activities for improving nutrients digestibility in broiler are closely associated with the effects of prebiotic in stimulating gut health (Iriyanti et al., 2018). The results proved that the villus growth directly inhibits the colonization of pathogenic bacteria in the intestine. Śliżewska et al. (2020) showed that the villi height of ileum, weight gain, and final weight gain increased significantly compared to the control group. These results can be indications of the increased intestine villi height that increase nutrients absorption in the intestine that eventually increases body weight gain and feeds efficiency.

The damaged villi will decrease nutrients absorptions in the digestive tract of poultry (Mishra \& Jha, 2019). In this study, there was an interesting result that L. plantarum and S. cerevisiae without inulin showed the poorer performance of intestinal villi compared with the other groups. These results confirmed that probiotics have a synergistic effect with inulin. Synergies between prebiotics and probiotics were reported by Sohail et al. (2012), that the synbiotic increased villi height and crypt depth.

Metabolic processes of energy and protein metabolism are supported by the presence of probiotic which may relate to the growth of intestinal villi (Kavoi et al., 2016; Kridtayopas et al., 2019). The results of the present study strongly confirm that treatment with a combination of probiotics and inulin significantly improves energy and protein metabolisms, as are indicated by the increase in ME and NR values (Table 3). Addition of inulin at the levels of $0.5 \%-1.0 \%$ possibly increased the viability of L. plantarum AKK30 and S. cerevisiae B18 in the broiler intestine. Short-chain fatty acids (SCFAs) produced from inulin fermentation might be used as an energy source for the growth of probiotics in the digestive tract. This synergistic mechanism was previously reported by Wang et al. (2019) that L. plantarum ZLP001 growth was synergistically supported by fructo-oligosaccharide addition. The microbial colonization of synbiotic in the intestine inhibited the growth and activities of pathogenic bacteria in the intestine (Villagrán-de la Mora et al., 2019), which eventually enhanced the absorptions of glucose and amino acids (Jiang et al., 2020).
Dietary inulin has a potency for altering microbial composition in the digestive tract through the inducing the growth of bacteria producing SCFAs (Hoffman et al., 2019). Kowalczuk-Vasilev et al. (2017) recommended that the administration of inulin in broiler diets was 4-6 g per $\mathrm{kg}$ of mixture $(0.4-0.6 \%)$. In this study, the level of inulin addition at $0.5-1.0 \%$ in combination with probiotics increased the performance index of the experimental broiler. However, the increased level of inulin to $1.5 \%$ in combination with probiotics had no significant influence on broiler performance compared to control. A different result was observed by Huang et al. (2015) that inulin supplementation at $0.5 \%-1.5 \%$ of diet had no effect on growth performance, however, it could improve the intestinal immune parameter of broilers.

The synergetic effect between microorganism/ probiotics in nutrients metabolism might be enhanced by the addition of inulin in the growth medium (deSouza Oliveira et al., 2012). We found that probiotics, in combination with inulin addition at $0.5-1.0 \%$ increased energy and protein metabolism (Table 3 ). These results were also suggested by the other studies that synbiotic between bacteria-yeast probiotic with inulin reduced pathogenic bacteria in the gut (Gao et al., 2017) that eventually increased energy metabolism (Yadav \& Rajesh, 2019).

Evaluation of dietary probiotic with prebiotic supplementation on growth performance was reported by several studies. Ghasemi et al. (2010) revealed that administration of $0.1 \%$ and $0.15 \%$ symbiotic (Enterococcus faecium with inulin) increased BWG, and improved FCR compared to non-supplementation groups in broiler. Mookiah et al. (2014) also reported that the administration of synbiotic (a combination of iso-malto oligosaccharides, and probiotic mixture from 11 strains of Lactobacillus spp.) significantly increased BWG and feed efficiency. A combination of yeastderived carbohydrates and probiotics increased BWG of pullets (Yitbarek et al., 2015). Yang et al. (2018) reported that Lactobacillus plantarum had antibacterial activity and affected nutrient digestibility, whereas $\beta$-glucan and chitin content in Saccharomyces cerevisiae inhibited the growth of pathogenic bacteria in the intestine (Anwar et al., 2017), and improved the intestinal health (Sun \& Kim, 2019).

The improved feed efficiency of broilers due to the presence of probiotic was related to the increased digestion efficiency and nutrient absorption processes (Istiqomah et al., 2013). Therefore, inulin provides nutrients required for the growth of probiotics (Pranckute et al., 2016) that eventually stimulates the growth of health-promoting bacteria in the gastrointestinal tract (Śliżewska et al., 2020). Probiotics produce anti-bacterial compounds in lactic acid bacteria and yeast, implying the reduction of pathogenic bacteria growth and colonies that eventually improve the intestinal environment for digesting nutrients (Villagrán-de la Mora et al., 2019). Those studies suggested the beneficiary effect of dietary probiotics in combination with prebiotic on broiler performance, as was reported in this study.

In this study, the experimental broiler mortality in treatment of probiotics combined with inulin signifi- 
cantly decreased. This effect may be associated with the potential role of probiotics in pathogenic infection risk. Kalia et al. (2017) reported that coccidiosis risk had been successfully reduced by the administration of probiotics consisting of B. coagulans and S. cerevisiae in broiler diet. The performance index of broiler treated by administration of probiotic L. plantarum and S. cerevisiae and inulin $(0.5 \%$ and $1 \%)$ in this study showed the highest performance of growth parameter and intestinal morphology. These results suggest that the use of probiotic-prebiotic (synbiotic) positively influences feed efficiency and performance index in broiler as previously reported by Salah et al. (2019).

\section{CONCLUSION}

Probiotics consisting of L. plantarum AKK30 and S. cerevisiae $\mathrm{B} 18$ in combination with or without inulin can be used as broiler's feed additive. Probiotics combined with either $0.5 \%$ or $1.0 \%$ inulin improve growth performance, intestinal mucosa morphology, and nutrients utilization in broiler.

\section{CONFLICTS OF INTEREST}

The authors state that there is no conflict of interest about the materials and statements in this article.

\section{ACKNOWLEDGMENT}

Financial guarantee was supported by the INSINAS research program, Ministry of Research and Technology through the National Agency for Research and Innovation with letter of intent number 15/E/KPT/2019 and contract number 037/P/RPL-LIPI/INSINAS-1// II/2019. The authors would like to address appreciation for Mrs. M. Nurohmah, S.Pt., Ms. A. Windarsih, M.Pharm, and Bio-Feed Additive Research Group member for technical assistance during the experiment.

\section{REFERENCES}

Anwar, M. I., F. M. Muhammad, M. Awais, \& M. Akhtar. 2017. A review of $\beta$-glucan as a growth promoter and antibiotic alternative againts enteric pathogens in poultry. World Poult. Sci. J. 73: 651-661. https://doi.org/10.1017/ S0043933917000241

AOAC. 2005. Official Methods of Analysis of AOAC International 18th ed. Assoc. Off. Anal. Chem., Arlington.

Cohort. 2008.Costat-Coplot Version 6.311. Cohort Software798 Light House Ave. PMB320. Monterey. CA93940 and USA.

deSouza Oliveira, R. P., P. Perego, M. N. deOliveira, \& A. Converti. 2012. Effect of inulin on the growth and metabolism of a probiotic strain of Lactobacillus rhamnosus in co-culture with Streptococcus thermophilus. LWT Food Sci. Technol. 47: 358-363. https://doi.org/10.1016/j. lwt.2012.01.031

Gadde, U., W. H. Kim, S. T. Oh, \& H. S. Lillehoj. 2017. Alternatives to antibiotics for maximizing growth performance and feed efficiency in poultry: a review. Anim. Health Res. Rev. 18: 26-45. https://doi.org/10.1017/ S1466252316000207

Gao, Z., H. Wu, L. Shi, X. Zhang, R. Sheng, F. Yin, \& R. Gooneratne. 2017. Study of Bacillus subtilis on growth performance, nutrition metabolism and intestinal microflora of 1 to $42 \mathrm{~d}$ broiler chickens. Anim. Nutr. 3: 109-113. https://doi.org/10.1016/j.aninu.2017.02.002

Ghasemi, H., M. Shivazad, K. Esmaeilnia, H. Kohram, \& M.A. Karimi. 2010. The effect of synbiotic containing Enterococcus faecium and inulin on growth performance and resistance to coccidiosis in broiler chickens. J. Poult. Sci. 47: 149-155. https://doi.org/10.2141/jpsa.009065

Hoffman, J. D., L.M. Yanckello, G. Chlipala, T.C. Hammond, S.D. McCulloch, I. Parikh, S. Sun, S.J. Green, \& A.L. Lin. 2019. Dietary inulin alters the gut microbiome, enhances systemic metabolism and reduces neuroinflammation in an APOE4 mouse model. PloS One 14: e0221828. https:// doi.org/10.1371/journal.pone.0221828

Huang, Q., Y. Wei, Y. Lv, Y. Wang, \& T. Hu. 2015. Effect of dietary inulin supplements on growth performance and intestinal immunological parameters of broiler chickens. Livest. Sci. 180: 172-176. https://doi.org/10.1016/j.livsci.2015.07.015

Iriyanti, N., B. Hartoyo, \& S. Suhermiyati. 2018. Performance and intestinal profiles of Tegal duck fed ration supplemented with prebiotics. Trop. Anim. Sci. J. 41: 15-21. https://doi.org/10.5398/tasj.2018.41.1.15

Istiqomah, L., S. N. Hayati, E. Damayanti, H. Julendra, A. A. Sakti, \& T. Untari. 2013. Performance and meat quality of broilers infected with Escherichia coli and administered with bio additive, probiotic, and antibiotic. Med. Pet. 36: 14-20. https://doi.org/10.5398/medpet.2013.36.1.14

JCI (Japfa Comfeed Indonesia). 2020. Brochure MB202 and MB402. PT. Multi Breeder Japfa Comfeed Indonesia. https://www.japfacomfeed.co.id/en/product-and-services/ product-detail/doc-broilercommercial. [17 April 2020].

Jiang, S., A. A. Mohammed, J. A. Jacobs, T.A. Cramer, \& H. W. Cheng. 2020. Effect of synbiotic on thyroid hormones, intestinal histomorphology, and heat shock protein 70 expression in broiler chickens reared under cyclic heat stress. Poult. Sci. 99: 142-150. https://doi.org/10.3382/ps/pez571

Kalia, S., V. K. Bharti, D. Gogoi, A. Giri, \& B. Kumar. 2017. Studies on the growth performance of different broiler strains at high altitude and evaluation of probiotic effect on their survivability. Sci. Rep. 11: 46074. https://doi. org/10.1038/srep46074

Kavoi, B. M., D.W. Gakuya, P.N. Mbugua, \& S.G. Kiama. 2016. Effects of dietary Moringa oleifera leaf meal supplementation on chicken intestinal structure and growth performance. J. Morphol. Sci. 33:186-192. https://doi.org/10.4322/ jms095915

Kowalczuk-Vasilev, E., E. R. Grela, W. Samolinska, R. Klebaniuk, B. O. Ż. E. N. A. Kiczorowska, R. Krusinski, A. Winiarska-Mieczan, K. Kepka, \& M. Kwiecien. 2017. Blood metabolic profile of broiler chickens fed diets with different types and levels of inulin. Med. Wet. 73: 774-780. htpps://doi.org/10.21521/mw.5821

Kridtayopas, C., C. Rakangtong, C. Bunchasak, \& W. Loongyai. 2019. Effect of prebiotic and synbiotic supplementation in diet on growth performance, small intestinal morphology, stress, and bacterial population under high stocking density condition of broiler chickens. Poult. Sci. 98: 4595-4605. htpps://doi.org/10.3382/ps/pez152

Leeson, S. \& J. D. Summers. 2005. Commercial Poultry Nutrition. Nottingham University Books, Guelph, Ontario, Canada.

McGlone, J. 2010. Guide for The Care and Use of Agricultural Animals in Research and Teaching. Fed. Anim. Sci. Soc. $3^{\text {rd }}$ ed. https://www.aaalac.org/. [5 May 2019].

Mehdi, Y., M. P. Létourneau-Montminy, M. L. Gaucher, Y. Chorfi, G. Suresh, T. Rouissi, S. K. Brar, C. Côté, A. A. Ramirez, \& S. Godbout. 2018. Use of antibiotics in broiler production: global impacts and alternatives. Anim. Nut. 4: 170-178. https://doi.org/10.1016/j.aninu.2018.03.002 
Mishra, B. \& R. Jha. 2019. Oxidative stress in the poultry gut: potential challenges and interventions. Front. Vet. Sci. 6: 60. https://doi.org/10.3389/fvets.2019.00060

Mohammed, A. A., S. Jiang, J. A. Jacobs, \& H. W. Cheng. 2019. Effect of a synbiotic supplement on cecal microbial ecology, antioxidant status, and immune response of broiler chickens reared under heat stress. Poult. Sci. 98: 4408-4415. https://doi.org/10.3382/ps/pez246

Mookiah, S., C. C. Sieo, K. Ramasamy, N. Abdullah, \& Y. W. Ho. 2014. Effects of dietary prebiotics, probiotic and synbiotic on performance, caecal bacterial populations and caecal fermentation concentrations of broiler chickens. J. Sci. Food Agric. 94: 341-348. https://doi.org/10.1002/jsfa.6365

NRC (National Research Council). 1994. Nutrient Requirements of Poultry. $9^{\text {th }}$ Rev. ed. National Academy Press, Washington DC

Pranckute, R., K. Arnoldas, K. Nomeda, \& J. C. Donaldas. 2016. Combining prebiotics with probiotic bacteria can enhance bacterial growth and secretion of bacteriocins. Int. J. Bio. Macromol. 89: 669-676. https://doi.org/10.1016/j. ijbiomac.2016.05.041

Ricke, S. C., S. I. Lee, S. A. Kim, S. H. Park, \& Z. Shi. 2020. Prebiotics and the poultry gastrointestinal tract microbiome. Poult. Sci. 99: 670-677. https://doi.org/10.1016/j. psj.2019.12.018

Ripon, M. M. R., M. H. Rashid, M. M. Rahman, M. F. Ferdous, M. S. Arefin, A. A. Sani, M. T. Hossain, M. U. Ahammad, \& K. Rafiq. 2019. Dose-dependent response to phytobiotic supplementation in feed on growth, hematology, intestinal $\mathrm{pH}$, and gut bacterial load in broiler chicken. J. Adv. Vet. Anim. Res. 6: 253-259. htpps://doi.org/10.5455/ javar.2019.f341

Salah, A. S., M. S. El-Tarabany, \& M. A. Ali. 2019. Impact of dietary supplementation with a synbiotic, organic acids or their combination on growth performance, carcass traits, economic efficiency, jejunum histomorphometry and some blood indices of broiler chickens. Anim. Prod. Sci. 59: 13181326. https://doi.org/10.1071/AN18156

Sarangi, N. R., L. K. Babu, A. Kumar, C. R. Pradhan, P. K. Pati, \& J. P. Mishra. 2016. Effect of dietary supplementation of prebiotic, probiotic, and synbiotic on growth performance and carcass characteristics of broiler chickens. Vet. World 9: 313-319. https://doi.org/10.14202/vetworld.2016.313-319

Sibbald, I. R. \& M. S. Wolynetz. 1985. Relationships between estimates of bioavailable energy made with adult cockerels and chicks: effects of feed intake and nitrogen retention. Poult. Sci. 64: 127-138. https://doi.org/10.3382/ps.0640127

Śliżewska, K., P. Markowiak-Kopeć, A. Żbikowski, \& P. Szeleszczuk. 2020. The effect of synbiotic preparations on the intestinal microbiota and her metabolism in broiler chickens. Sci. Rep. 10: 1-13. https://doi.org/10.1038/ s41598-020-61256-Z

Sofyan, A., M. Angwar, H. Herdian, E. Damayanti, L. Istiqomah, A. Febrisiantosa, H. Julendra, M. H. Wibowo, \& T. Untari. 2012. Performance enhancement and immunity profile of broiler treated feed additive containing lactic acid bacteria and Ganoderma lucidum. Med. Pet. 35: 201-206. https://doi.org/10.5398/medpet.2012.35.3.201
Sofyan, A., R. S. H. Martin, E. B. Laconi, A. Jayanegara, H. Julendra, E. Damayanti, \& A. E. Suryani. 2019. The assays of bacteria-yeast consortia as probiotics candidates and their influences on nutrients utilization of quails diet. Trop. Anim. Sci. J. 42: 196-202. https://doi.org/10.5398/ tasj.2019.42.3.196

Sohail, M. U., M.E. Hume, J. A. Byrd, D.J. Nisbet, A. Ijaz, A. Sohail, M. Z. Shabbir, \& H. Rehman. 2012. Effect of supplementation of prebiotic mannan-oligosaccharides and probiotic mixture on growth performance of broilers subjected to chronic heat stress. Poult. Sci. 91: 2235-2240. https://doi.org/10.3382/ps.2012-02182

Sun, H. Y, \& I. H. Kim. 2019. Dietary supplementation of mixed yeast culture derived from Saccharomyces cerevisiae and Kluyveromyces maxianus: Effects on growth performance, nutrient digestibility, meat quality, blood parameters, and gut health in broilers. J. Poult. Sci. 56: 140-147. https://doi. org/10.2141/jpsa.0180052

Tayeri, V., A. Seidavi, L. Asadpour, \& C. J. C. Phillips. 2018. A comparison of the effects of antibiotics, probiotics, synbiotic and prebiotics on the performance and carcass characteristics of broilers. Vet. Res. Commun. 42: 195-207. https:// doi.org/10.1007/s11259-018-9724-2

Titze, B. \& G. Christel. 2016. Volume scanning electron microscopy for imaging biological ultrastructure. Biol. Cell. 108: 307-337. https://doi.org/10.1111/ boc.201600024

Villagrán-de la Mora, Z., K. Nuño, O. Vázquez-Paulino, H. Avalos, J. Castro-Rosas, C. Gómez-Aldapa, A. C. Angulo, A. Felipe, \& A. Villarruel-López. 2019. Effect of a synbiotic mix on intestinal structural changes, and Salmonella typhimurium and Clostridium perfringens colonization in broiler chickens. Animals 9: 777. https://doi.org/10.3390/ ani9100777

Wang, J., S. Wang, H. Liu, D. Zhang, Y. Wang, \& H. Ji. 2019. Effects of oligosaccharides on the growth and stress tolerance of Lactobacillus plantarum ZLP001 in vitro, and the potential synbiotic effects of L. plantarum ZLP001 and fructooligosaccharide in post-weaning piglets. J. Anim. Sci. 97: 4588-4597. https://doi.org/10.1093/jas/skz254

Warnes, G.R., B. Bolker, L. Bonebakker, R. Gentleman, W. Huber, A. Liaw, T. Lumley, M. Maechler, A. Magnusson, S. Moeller, M. Schawartz, B. Venables, \& T. Galili. 2019. gplots: various $\mathrm{R}$ programming tools for plotting data, version 3.0.1.1. https://cran.r-project.org/web/packages/ gplots/index.html. [7 April 2019].

Yadav, S, \& J. Rajesh. 2019. Strategies to modulate the intestinal microbiota and their effects on nutrient utilization, performance, and health of poultry. J. Anim. Sci. Biotech. 10: 2. https://doi.org/10.1186/s40104-018-0310-9

Yang, Y., J. D. Latorre, B. Katri, Y. M. Kown, B. W. Kong, K. D. Teague, L. E. Graham, D. Wolfenden, B. D. Mahaffey, M. Baxter, X. Hernandez-Velasco, R. Moreno-Guzman, B. M. Hargiz, \& G. Tellez. 2018. Characterization and evaluation of lactic acid bacteria candidates for intestinal epithelial permeability and Salmonella typhimurium colonization in neonatal turkey poults. Poult. Sci. 97: 515-521. https://doi. org/10.3382/ps/pex311

Yitbarek, A., H. Echeverry, P. Munyaka, \& J. C. RodriguezLecompte. 2015. Innate immune response of pullets fed diets supplemented with prebiotics and synbiotic. Poult. Sci. 94: 1802-1811. https://doi.org/10.3382/ps/pev147 